\title{
Teaching history in a global age
}

\author{
Anthony Hourdakis* - University of Crete, Greece, and Zhengzhou University, \\ China \\ Pella Calogiannakis - University of Crete, Greece, and Zhengzhou University, \\ China \\ Tien-Hui Chiang - Zhengzhou University, China
}

\begin{abstract}
Researchers in the teaching of modern global history generally focus on historical issues that have reshaped our world, including decolonization, social democracies, revolutions, terrorism, religions, competition in labour markets and the role of superpowers. This article attempts to explore global study through which young people may understand both the outside world and themselves. The aim is to reframe the way in which history is taught in schools, seeing it as part of the whole curriculum that makes a contribution to both the values of personal development and to citizenship with a focus on the world's history. History needs to develop a political intelligence through teaching global history. Based upon the paper's theoretical framework, curriculum developers can create global history syllabuses and pedagogies.
\end{abstract}

Keywords: citizenship; critical thinking; cross-cultural interaction; global history; history teaching; political intelligence; world history; history curriculum

\section{Introduction}

Historical knowledge and understanding is a precondition of political intelligence. History education teaches students to examine controversial issues through studying primary and secondary sources, to consider the validity of historical evidence, to discuss the causes and effects of changes over time and to understand why there are different interpretations of the past (Slater, 1995; Stradling, 2003: 13). Our aim is both to consider curricular issues at a national level and to suggest a new approach to global history as an integral part of the curriculum to support students making connections across world history - to encourage them to ask questions and to examine human history through social, cultural or economic lenses. The emphasis should be on critical thinking and on global human values (Geyer and Bright, 1995: 1037; Burns, 2006: 368). In contrast, school global history today predominantly highlights an ethnocentric narrative that aims to cultivate national consciousness, rather than promote critical thinking and multi-ethnic and multicultural awareness. Students usually passively assimilate this national master narrative as uncontested historical truth. Nothing in its content indicates that its authors have selected, interpreted and constructed it as an interpretation (Coulby, 1995; Jenkins, 1997).

As well as their own culture, students should appreciate the world's many other cultures, and recognize that there is a long history of common problems across them. Naturally, current problems do not reproduce those of the past. However, many aspects of modern global history are centred around crucial historical issues and 
emerging problems that have reshaped our world: decolonization, social democracies and reforms, revolutions, wars, terrorism, war crimes, religious conflicts, competition in free-market economies, and ultimately globalization and the role of superpowers (Turk et al., 2014: 3).

Analysis of current issues, based on relevant historical evidence and knowledge of the histories of the world's cultures, can contribute to the promotion of the mutual understanding, respect and citizenship that are required in our increasingly pluralistic society. This knowledge will contribute not only to the education of students as global citizens, but also to their individual development. Historical memory is the key to selfidentification, to seeing one's position in time and connection with all humankind (NCHS, 1995; Slater, 1995: 143-8).

Hence, it is high time to redefine history and history education in a global era, through thinking inclusively and universally. Many argue that the idea of 'political intelligence' arises as a need for students to learn about the interconnection of cultures, while recognizing they grow up in countries each of which has a particular national past, culture, beliefs, values and governance. Therefore, they first need to learn to think critically about and understand their own culture. World history is a history without a specific geographical focus, but if we start from the local, it provides national, regional and global perspectives (Peyrot, 1986: 337; 1990: 19-23; 1999: 21; Moniot, 1993). Collingwood (1946: 282-302) states that the goal of history is not just to understand an event but also the idea expressed in it. Local history enables children to learn to carry out historical enquiries, starting with questions and questioning. Local history enables them to make links between past and present culture, society and changes through time. If children learn to think historically about their own locality, later on they can learn to make connections between local, national and global communities, applying the processes of critical, historical thinking that they have learned.

\section{Towards a theory of global history}

\section{Critique of current history education}

In recent decades, the rapid transformation of living conditions has made it necessary to take a new look at the past. The globalization of issues, concerns, values and problems, from the demographic, sociopolitical, environmental and cultural perspectives, has called into question the orientation of traditional historiography, with its focus on the history of Western Europe and the Mediterranean (Coulby, 1995). More specifically, surveys carried out in Greece to ascertain whether the European and global dimensions were represented in history teaching found stereotypical images of foreigners and few universal themes. Greek history programmes strongly reflect the traditional view of its national past (Apostolidou, 2017: 2). Similarly, in England the history curriculum is based on local, regional, national and international perspectives, but with a clear English focus (DfE, 2013). History curricula that do not address the cultural pluralism that characterizes our world are clearly inadequate. They superficially treat issues arising from racial and ethnic discrimination without consideration of their wider political, economic, cultural and social context in the non-Western world. (Robbins, 1993; Farnen, 1994; Ivrideli et al., 2003). Table 1 gives examples of historical content that is frequently studied and the dimensions of that content that are often omitted. 
Table 1: Historical content that is frequently studied and the dimensions of that content that are often omitted

\begin{tabular}{|c|c|}
\hline We have often studied: & but not: \\
\hline the past of the West & the past of the world \\
\hline the past of nations & $\begin{array}{l}\text { the cultural and educational connections } \\
\text { between them }\end{array}$ \\
\hline the past of white peoples & the past of peoples of colour \\
\hline the past of ethnic majorities & the past of ethnic minorities and refugees \\
\hline $\begin{array}{l}\text { the past of men and the powerful peoples } \\
\text { of the world }\end{array}$ & $\begin{array}{l}\text { gender history, history of the weak and } \\
\text { hindered peoples of the world }\end{array}$ \\
\hline the past in general & $\begin{array}{l}\text { its connection with/relation to the present } \\
\text { and future }\end{array}$ \\
\hline \multicolumn{2}{|l|}{ While on the epistemological level, } \\
\hline We usually emphasize: & but not: \\
\hline the history of teaching & the history of learning \\
\hline the history of mind & $\begin{array}{l}\text { the history of body and feelings (focus } \\
\text { on conceptual history and historical } \\
\text { constructivism) }\end{array}$ \\
\hline the history of ideas/thought & the history of consciousness \\
\hline $\begin{array}{l}\text { the history of particular systems and } \\
\text { institutions }\end{array}$ & $\begin{array}{l}\text { the history of manners and the crisis } \\
\text { response (manners are an indication of } \\
\text { profounder virtues: sensitivity, community } \\
\text { spirit and moral strength) }\end{array}$ \\
\hline the history of legislation & $\begin{array}{l}\text { the social history (focus on opinion), folk- } \\
\text { memories (focus on stereotypes), } \\
\text { international perspectives (identification } \\
\text { of trends) }\end{array}$ \\
\hline
\end{tabular}

Without including the content in the second column of Table 1, global history curricula do not reflect and include key global issues that students need to consider and understand. This concern reframes both what and how global history should be taught in schools, raising the fundamental problem that developers of national curricula marginalize, or even totally ignore, the global dimension. But, as an element in school curricula, we specifically prescribe a global history curriculum concerned with connections between the national, international and global - the main theme of this paper. As such, a global approach to the history of the world represents an important educational innovation and development. Distinctively, even uniquely, it deals both with the entire world rather than with a particular region, country or continent, and with all mankind's past, as opposed to the past of Western or nonWestern-oriented jurisdictions (Hourdakis, 1996; Mazlish and Buultjens, 1993: 1, 113ff.; Friedman, 2007).

\section{Global and world history}

Global history is distinguished from other types of history in that it centres on humanity as a whole. Not all that is called world history is global history. Global history deals with themes that involve 'big structures, large processes and huge comparisons', and must be research-oriented (Schäfer, 1993: n.p.). On the contrary, world history is frequently 
a label for a collection of narratives of particular nations, or regions, which emphasize the uniqueness and superiority of each, and draw none or few generalizations that cut across narrow, regional lines (Engle, 1971: 438-42; Mazlish, 1998: 385-95; Barnes, 2015). Moreover, most world history texts present a Western point of view with a major imbalance of content, and as such are strongly biased with distorted perspectives (see Table 1) (Kishlansky et al., 1995; Craig et al., 1997; Reddy, 2001; Pomeranz, 2002: 539-90; Rosenwein, 2010; Singer, 2011: 77-87; Scheer, 2012).

Such world history presents itself as how to study the world's past. Accordingly, it does not emphasize linkages between societies over large areas. Moreover, it fails to discuss how people in different places and times have come up with unique solutions to common problems. It promotes the ideal of cultural homogeneity, which has been constructed from the idea of the European nation state, and projects it onto the history of the Third World countries. Additionally, it uses concepts and unit analysis more appropriate to nation states than to an integrated modern polity. It pays no attention to discussion about global and local interactions. In addition, it uses terms such as 'emergence', 'crisis', 'rebirth', 'reformation' and 'intellectual revolution' that are appropriate in their Western, European context. These concepts are represented by far less forceful words in other civilizations. The prevalent themes in world history arise from a military, economic and political point of view, and other important themes, such as philosophy, culture, ideology, war crimes and religion, are unacceptably excluded (Gills and Thompson, 2006: 44ff.). World history considers women, often disregarded in history textbooks, but condescendingly looks at them mainly from the perspective of Western conceptualization of women. Finally, concepts such as progress or exploitation are also usually omitted, while if integration is discussed, it is almost solely from a Western economic perspective (Singer, 2011: 77-87).

\section{Approaching global history}

The global approach to the history of the world attempted here represents a significant departure from modern educational practice. The distinctive feature of this approach is that it deals with the entire world, rather than with a particular country or region. It deals not only with the history of Western man, but also with that of all humanity (Hourdakis, 1996; Mazlish and Buultjens, 1993: 1, 113ff.; Friedman, 2007). Mazlish (2006: 109), writing about globalization, refers to the exploitation of space, satellite communications, multinational corporations, environmental problems and nuclear threats and terrorism. Mazlish and Iriye (2005: 254) see terrorism as an excellent topic through which to examine many contradictory aspects of globalization. In global history, there is a focus on the whole system. As a cross-cultural, transnational and interdisciplinary field of research, it tries to investigate the emergence and present character of multiple local activities that have worldwide connections, consequence and significance.

\section{Questions arising in teaching global history}

Of course, a global approach is not without difficulties (Schäfer, 1993; Engle, 1971: 438-42). For example, scholars ask whether or not a 'global history' should try to cover the history of the entire world, or should it focus on those areas where different cultures interact across large regions? Cross-cultural interactions began to influence human affairs from the earliest times, and perhaps they should be the basis for establishing a periodization of world history (Brown, 1987: 239-311). 
As historians view the past from broad, comparative and global viewpoints, they will have to consider the role of cross-cultural interactions (Bentley, 1996: 770), and patterns of continuity and change that reflect the experiences of many, but not all, people (ibid.: 750). When historians and teachers approach the past from global points of view, and examine procedures that cross the boundary lines of societies and cultural regions, the problems of periodization become more difficult. Historians have realized that periodization based on the experiences of Western civilization, or any other particular civilization, do not adequately explain the processes of change in others. The problems of periodization are still present even when historians take global approaches to the past and analyse human experiences from extensive and comparative perspectives (Bentley, 1996: 749-50; Singer, 2011: 39).

A new global history can be based on two basic propositions. First, we should free ourselves from a traditional viewpoint that locks history up within national boundaries. According to Tait (2015), it is important for students (and politicians) to accept that history is not the private property of any one nation, and that, while we were once taught that our views were 'the truth', thanks to the dissemination of knowledge and the World Wide Web, we are no longer so naive. Second, new global history necessitates using diverse historical sources. Historians have tried to find a way to apply the methods of enquiry of history as a discipline to global history. This involves the establishment of methods of classifying and organizing the excessive amount of historical information available so as to recognize patterns of continuity, development and change.

It is often argued that only by understanding substantive concepts such as 'nation', 'society', 'culture' and 'education' as bundles of relationships, and by replacing them in the field from which they were abstracted, can we hope to avoid misleading inferences and to increase understanding. Many of us grew up believing that the West has a chronological genealogy, according to which ancient Greece begot Rome, Rome begot Christian Europe, Christian Europe begot the Renaissance, the Renaissance the Enlightenment, and the Enlightenment political democracy and the Industrial Revolution (Singer, 2011: 39ff., 77-87). The American Revolution, and industrialization combined with democracy, helped to shape a nation state of the United States of America that embodied the rights to life, liberty and the pursuit of happiness. This view of the Western world's developmental genealogical chronology from 'Plato to Nato' is misleading because it turns history into a moral success story, a race in time in which each runner passes on the torch of Western civilization to the next in the relay.

History is thus converted into a tale about the furtherance and development of virtue, about how the virtuous win out over the evil ones. Frequently, this turns into a tautology whereby the winners prove that they are virtuous and good by winning. The point is more than academic. By endowing nations, societies or cultures with the qualities of internal homogeneity and externally distinctive boundaries, we create a model of the world as a global pool hall, in which the entities spin off each other like hard, round billiard balls (Wolf, 1982: 3-7). Wolf explains that the notion of separate cultures is no longer valid. Global interaction has modified and transformed all cultures with their discrete regional origins, and none of them remain in their pristine state.

Here, global history as explanation of the present is radical revisionist history. As already argued, global history rebuts the misunderstanding, distortion and misinterpretation of world history. Knowledge of what Nietzsche (1976: 12-17) termed 'critical history' is required; this can contribute to the creation of personality, by understanding its emergence in the course of human history (Leont'ev, 1994: 9-13). From the perspective of critical theory, in the realization of identity and personality, 
the most important category is history - not society, not even emancipation. In each period of human history, personal identity has been produced under different social conditions, and thus itself became different. There is no such thing as an ahistoric human identity. That is why critical pedagogy examines the quality of the present social and cultural environment of Western society as the condition for the development of humanity (Newman and Holzman, 1993: 106ff.; Wertsch et al., 1995). Today, we need teachers who are able to act as agents for global change. History is probably one of the subjects that can educate students to be empathetic, and have mutual understanding and tolerance, as well as have deep respect for all the world's nationalities (Bunge, 1994: 4).

In a postmodern world system in which electronic media, migration and travel have enabled the creation of an entirely sociocultural universe, terms such as 'centre' and 'periphery' are no longer appropriate or of value (Appadurai, 1990; Clifford, 1988, 2013). The title of the 1991 New York State Social Studies Review and Development Committee's report One World, Many Peoples: A declaration of cultural interdependence (see Buell, 1993: 62) recognized the changed global paradigm that underpins the concept of global history.

\section{From theory to practice}

\section{The method}

It is clear that an educational curriculum development and research methodology is needed to create a new global history. The distinction between content and process could be the framework for designing syllabuses and pedagogy that meet teachers' needs to teach global history themes, topics and concepts. But in global history we should teach a comprehensive history that all can share. How this might look in curricular terms is challenging. Tackling curriculum development at an abstract level enables the emergence of a coherent, interesting and challenging framework. In creating effective, challenging and stimulating global history pedagogy, a primary task is to identify developments that involved and affected humanity on a global scale over a long period of time. It is crucial to encourage students to ask large, searching questions about the human past, to compare patterns of continuity and change in different parts of the world, and to examine the histories and achievements of particular peoples or civilizations.

In addition, we need to promote students' global thinking. So, we must ask: What does global thinking mean? What processes help learning about it? And finally, as already noted, what pedagogy is effective for teaching it? The emphasis on pedagogy should be applied to the teaching of, for example, multiculturalism and the environment. From this perspective, global history in an era of globalization could play an important role in the development of a global consciousness, in accordance with the synoptic scheme in Table 2 (Weil, 1990: 63; Nielsen, 2013). 
Table 2: The relationship between global history and global consciousness

\begin{tabular}{|c|c|c|}
\hline \multicolumn{3}{|c|}{ Global history } \\
\hline Nature & Man & Society \\
\hline \multicolumn{3}{|c|}{ Global consciousness } \\
\hline \multirow[t]{2}{*}{ Planetary ecology } & Self-ecology & Social ecology \\
\hline & $\begin{array}{c}\text { Environmentally responsible } \\
\text { behaviour as a form of self- } \\
\text { interest }\end{array}$ & $\begin{array}{l}\text { A moral economy that } \\
\text { moves beyond scarcity } \\
\text { and hierarchy towards a } \\
\text { world that re-harmonizes } \\
\text { human communities with } \\
\text { the natural world }\end{array}$ \\
\hline Planetary consciousness & Personal consciousness & Social consciousness \\
\hline $\begin{array}{c}\text { The idea that human beings } \\
\text { are members of a planetary } \\
\text { society as much as they are } \\
\text { members of nations, cities, } \\
\text { villages }\end{array}$ & $\begin{array}{c}\text { Awareness within and beyond } \\
\text { oneself }\end{array}$ & $\begin{array}{l}\text { Awareness of the } \\
\text { problems and injustices } \\
\text { that affect society }\end{array}$ \\
\hline
\end{tabular}

Here it is useful to mention Jerome Bruner's MACOS (or Man: A Course of Study) project in the United States in the 1970s, based on his 'theory of instruction'. MACOS was developed to teach children to understand what it means to be human, thus rebutting ethnocentrism and racism through studying humans as a homogeneous species to which we all belong (Conway, 2007: 60-1). Table 3 shows the way in which history has previously been taught, and a proposed new approach.

Table 3: The previous paradigm and a new paradigm for teaching history

\begin{tabular}{|c|c|c|}
\hline & Previous paradigm & New paradigm \\
\hline \multirow{2}{*}{$\begin{array}{l}\text { Concept of history } \\
\text { teaching }\end{array}$} & \multirow[t]{2}{*}{ Information } & Formation \\
\hline & & Education of the personality \\
\hline $\begin{array}{l}\text { Concept of student } \\
\text { of history }\end{array}$ & $\begin{array}{l}\text { Student of history as teaching } \\
\text { 'object' }\end{array}$ & $\begin{array}{l}\text { Student of history as teaching } \\
\text { 'subject' }\end{array}$ \\
\hline \multirow{3}{*}{$\begin{array}{l}\text { Field of historical } \\
\text { action }\end{array}$} & History is personally irrelevant & History is personally relevant \\
\hline & \multirow[t]{2}{*}{$\begin{array}{l}\text { Acquisition of historical } \\
\text { knowledge }\end{array}$} & $\begin{array}{l}\text { Transformation of the whole } \\
\text { personality }\end{array}$ \\
\hline & & $\begin{array}{l}\text { History is a problem-solving } \\
\text { discipline }\end{array}$ \\
\hline \multirow[t]{3}{*}{$\begin{array}{l}\text { Agents of history } \\
\text { education }\end{array}$} & $\begin{array}{l}\text { School as the only agent of } \\
\text { history education }\end{array}$ & \multirow{2}{*}{$\begin{array}{l}\text { Family, school and society in } \\
\text { a concrete effort for history } \\
\text { education }\end{array}$} \\
\hline & \multirow[t]{2}{*}{ Teacher as 'instructor' } & \\
\hline & & Teacher as animator/facilitator \\
\hline $\begin{array}{l}\text { Concept of } \\
\text { evolution }\end{array}$ & $\begin{array}{l}\text { Evolution terminates in } \\
\text { adolescence }\end{array}$ & Evolution continues to the adult \\
\hline Type of formation & $\begin{array}{l}\text { Predominance of the historical } \\
\text { specialization }\end{array}$ & $\begin{array}{l}\text { General education precedes the } \\
\text { historical specialization }\end{array}$ \\
\hline
\end{tabular}




\begin{tabular}{lll}
\hline & Previous paradigm & New paradigm \\
\hline $\begin{array}{l}\text { Orientation of } \\
\text { values }\end{array}$ & $\begin{array}{l}\text { Competition, power, } \\
\text { possessiveness, celebrity in } \\
\text { history }\end{array}$ & $\begin{array}{l}\text { Pragmatic and ethical values: } \\
\text { simplicity, cooperation, } \\
\text { generosity, participation } \\
\text { equality, equanimity }\end{array}$ \\
$\begin{array}{ll}\text { Method of history } \\
\text { teaching }\end{array}$ & $\begin{array}{l}\text { Passive method: teacher teaches } \\
\text { and student listens }\end{array}$ & $\begin{array}{l}\text { Active method: teacher of history } \\
\text { is an adviser }\end{array}$ \\
& $\begin{array}{l}\text { History is a descriptive subject, } \\
\text { not concerned with explanation }\end{array}$ & $\begin{array}{l}\text { Student of history is an active } \\
\text { researcher and teaches others }\end{array}$ \\
& History is a compendium of & History involves both description \\
primordial and inalienable facts & and explanation \\
& History is easier than mathematics & History is more difficult than \\
& mathematics
\end{tabular}

From a methodological point of view, periodization of global history makes sense at a relatively high level of generalization to make it comprehensible (NCHS, 1996). History in a global era should include the history of ethnicities, cultures and civilizations from around the world. Global history should selectively draw upon exemplars from the whole world to illuminate key themes, topics, and substantive and syntactic historical concepts.

In more detail, first this could involve historians comparing records from the past in order to describe the effects that geography and the environment have had on societies, including the development of urban centres, food, clothing, industry, agriculture, shelter, trade, education and other aspects of culture, as well as comparing and contrasting various aspects of family life, erudition, structures and roles in different cultures and in many eras with their own experience. The main ideas may be illustrated in folk tales, legends, myths and stories of heroism that disclose the history and traditions of various cultures around the world, and describe life in urban areas and communities of various cultures of the world at various times in their history.

Second, historians would obtain historical data to describe significant aspects of cultures of the world; to analyse their education, dance, music and arts; to draw conclusions about daily life and beliefs; and to explain customs related to important celebrations, traditions, rituals and ceremonies.

\section{A thematic structure}

As mentioned, some of the most important aspects of postmodernity are the redefinition of the 'borders' between different cultures (Vieux, 1994) and the identification of the criteria used in the process of justifying the policies and practices of Western society (Slater, 1995). Postmodernism rejects modern historical discourse, according to which history is treated as a chronologically defined and teleologically cognitive structure. On the contrary, it supports a view of history that is decentralized, discontinuous, fragmented and diverse (Giroux, 1990; Gregoriou, 2001).

In this context, how the past should be taught to students can be realized in three ways: first, through teaching that focuses on developing students as citizens; second, through teaching that aims to explain human history and make it intelligible; and third, through teaching of the notion of 'otherness' (Oakes and Lipton, 1999). This orientation appears to be the key to enriching school history with elements suitable 
for expanding the spiritual horizons of tomorrow's citizens (McKellar, 1999; Burke, 1991; Jenkins, 1997: 3).

In the framework of the new paradigm in education, a thematic structure can be proposed in order to promote students' political intelligence in our global age (see Table 4). Obviously, this table (and also the other tables in this study) might be applied differently in the curricula of different countries, since countries and jurisdictions are multicultural and include varying and contrasting histories, cultures, faiths, ideologies, customs, ceremonies, traditions, governance and lifestyles. The significance and differences of the proposed themes arise from their unique sociocultural and historical contexts (Sotshangane, 2002: 210-17).

Table 4: Concepts in global history that could be taught using a variety of teaching approaches

\begin{tabular}{|c|c|c|c|c|}
\hline References & Themes & Processes & Goals/values & Level of values \\
\hline $\begin{array}{l}\text { Nature } \\
\text { Man } \\
\text { Society } \\
\text { Globe }\end{array}$ & $\begin{array}{l}\text { Perception } \\
\text { Patterning } \\
\text { Abstraction } \\
\text { Connections } \\
\text { Reference to } \\
\quad \text { sources } \\
\text { Analysis }\end{array}$ & Historicity & $\begin{array}{l}\text { Knowledge } \\
\text { Clarity } \\
\text { Integrity } \\
\text { Understanding }\end{array}$ & Cognitive \\
\hline $\begin{array}{l}\text { Nature } \\
\text { Man } \\
\text { Society } \\
\text { Globe }\end{array}$ & $\begin{array}{l}\text { Culture } \\
\text { Multiple } \\
\text { perspectives } \\
\text { Responsibility }\end{array}$ & $\begin{array}{l}\text { Cross-cultural/ } \\
\text { comparisons }\end{array}$ & $\begin{array}{l}\text { Multicultural } \\
\quad \text { understanding } \\
\text { Altruism } \\
\text { Humanism } \\
\text { Harmony } \\
\text { Openness }\end{array}$ & Affective \\
\hline $\begin{array}{l}\text { Nature } \\
\text { Man } \\
\text { Society } \\
\text { Globe }\end{array}$ & $\begin{array}{l}\text { Justice } \\
\text { Liberty } \\
\text { Prejudice } \\
\text { Migrations } \\
\text { Interdependence } \\
\text { Violence } \\
\text { Peace } \\
\text { Wealth } \\
\text { Systems }\end{array}$ & $\begin{array}{l}\text { Synthesis and } \\
\text { systemic } \\
\text { thinking }\end{array}$ & $\begin{array}{l}\text { Globalism } \\
\text { Ecology and } \\
\text { humanity }\end{array}$ & Basic \\
\hline $\begin{array}{l}\text { Nature } \\
\text { Man } \\
\text { Society } \\
\text { Globe }\end{array}$ & $\begin{array}{l}\text { Objectivity } \\
\text { Bias } \\
\text { Paradigms } \\
\text { Acceptance of } \\
\quad \text { uncertainty } \\
\text { Complexity } \\
\text { Choice }\end{array}$ & $\begin{array}{l}\text { Enquiry } \\
\text { Participation }\end{array}$ & $\begin{array}{l}\text { Social } \\
\text { responsibility } \\
\text { and national, } \\
\text { supranational } \\
\text { citizenship }\end{array}$ & $\begin{array}{l}\text { Transpersonal/ } \\
\text { sociopolitical }\end{array}$ \\
\hline
\end{tabular}

Teaching diversity, cross-cultural interaction, multiculturalism and multi-ethnicity in global history could focus on the following concepts/themes:

- Personality: Respect for individual identity, personality, self-esteem and confidence leads to, and helps develop, positive concepts of self and others.

- Cultural characteristics: These might include values, patterns, ideologies, beliefs, traditions, customs, and behaviours that members of a group recognize, esteem and share, and which differentiate them from other groups. 
- The necessities of life: A fundamental need for all people.

- Social structure: This includes institutions such as family, clan, tribe, schools, religions, government and clubs.

- Symbiosis: For example, the mutual dependence/reliance of individuals and groups on one another for harmonious, cooperative existence.

- Interaction: Individuals and groups transmit messages through language, symbols, signs, behaviour, culture and education, and interact with each other.

- Misappropriation: This may be in the form of bias, exploitation, discrimination or stereotypes.

- Pluralism: This is defined as a societal state where different ethnic, racial, religious or social groups retain their identity while living and working harmoniously and effectively in society at large (Weaver, 1988: 108).

However, a vision for building global consciousness via the teaching of global history, as the Conference of the National Council for History Education in Miami (Manitoba Education and Training, 1993) proposed, could include some of the following elements: the concept of 'nation' in its global context; the revision of the curriculum and the preparation of world standards in global history; the abandonment of ethnocentric and Eurocentric mentality in historical research and history teaching; the critique of the ideological and political use of history; and the importance of a new imagination in history education.

\section{Course patterns and syllabus}

According to the ideas previously discussed, students who study global history should consider the hypothetical end-state of globality (that is, when barriers have fallen) from a universal perspective. Globality deals not with a particular history of a nation, but with the history of the whole world (Hourdakis, 1996) - see also the timescale of 'big history' (Christian, 2004: 79-105). In this area, a contemporary international bibliography identifies numerous curriculum guides, projects and studies (Bentley, 1996: 756).

Students should also discover ways in which they can gain additional knowledge in learning global history without distorting or misinterpreting its cultural aspects. Teachers could also discuss the use of ancient history as a means for students to learn about democracy and social justice (Yurco, 1994: 36-7; Kahne and Westeimer, 2003: 34-40; Aldrete, 2011: 65-70). This would involve the revision of the pedagogy for teaching about ancient civilizations, as in the response to teachers' requests for practical assistance in implementing a history-social science curriculum (Manitoba Education and Training, 1993: 86; Seminole County Board of Public Instruction, 1986: $14 \mathrm{ff} ., 21 \mathrm{ff}$.$) .$

Other concepts for a course on global history include education and culture; education, responsibility and citizenship within the concept of political organization; education and its relation to the economy, culture, technology and the labour market; and the national and supranational/global aspect of education and culture. The concept of man, in the context of nature and society, would be interesting, as well as the concept of social groups, including relations between majorities and minorities.

\section{Pedagogy and new visions: Hopes, prospects, developments}

The basis for global history pedagogy is that in a postmodern era it must enable the making of previously neglected but seminal global connections in their global 
context. For example, a global history textbook must treat equally Western, nonWestern and Third World global identities. We must also reject the imperialistic focus, register and imbalance implicit in many curricula and teaching resources, and call for their replacement. The pedagogic emphasis must be on critical thinking, and the prioritization of human dignity studied on a global scale to promote universal human values (Geyer and Bright, 1995: 1037; Burns, 2006: 368).

Currently there are many ways to teach, study and learn world history. Westernoriented historical and educational research has extensively investigated worldhistorical themes and topics (Brooks, 1991: 65-81; Curtin, 1991: 81-9; Mazlish and Buultjens, 1993; Mader, 2012: 1-15). Comparative studies of ancient, medieval and modern empires (McNeill, 1986, 1992; Greaves et al., 1990; Stearns et al., 2007) place the West in a global framework that involves the rise and fall of imperial powers and conflict between civilizations. Westernized world history also addresses a catholic range of histories, for example, of discovery, exploration, maritime empires, nomadic peoples and forced or voluntary migration, genocide, urbanization, finance, industry, trade, diasporas, travel and communication (Featherstone, 1990; Bentley, 1993; Chow, 1993; Goddard et al., 1994; Geyer and Bright, 1995: 1039-40; Hausen, 1996; Judt and Snyder, 2012). World history should now be concerned with the presentation of global issues through describing, analysing and interpreting, and promoting the world's diverse cultures within a common conceptual framework.

Global history does not reject world history or the comparative histories of civilizations, but it redefines the framework in which these paradigms are used (Geyer and Bright, 1995: 1059). With this aim, its task is to facilitate understanding of the characteristics that naturally create a single global community (Geyer and Bright, 1995: 1058-60; McCarthy, 2012: 73). As Schäfer (1993: n.p.) noted, 'Global history is the unwritten history of the twentieth century, and we have to find out how it can be written'.

\section{Conclusion}

The main task of a new world history today - that is, global history - is to relate the world's past to the era of globalization, interconnectedness and dependence - the global village. In this context, historians and teachers should try to represent a contemporary world arising from a melange of interconnected histories, which recognizes and respects diversity but accepts the need for a common response to global challenges that are putting the human race and its planet at risk. This needs imagination. With this aim, we need a school history that encourages human values, a history filled with colourful characters, a history that does not make the past superficially attractive or dispense false optimism for the future, a history that creates a greater interest in studying the possibility of a new global reality, which enhances human values, and values of brotherhood, sisterhood, peace, justice and equality (McCarthy, 2012).

\section{Notes on the contributors}

Anthony Hourdakis is a professor at the University of Crete, Greece. His research interests include: history of education, didactics of history and critical pedagogy. He is a Distinguished Visiting Professor (DVP) at Zhengzhou University, People's Republic of China and Director of Xeniseum (Educational Museum, University of Crete). He is the author of 12 books and about eighty articles in several different languages. 
Pella Calogiannakis is a professor at the University of Crete, Greece. Her research interests are related to methodological issues of comparative education and political socialization. She is a DVP of Zhengzhou University, People's Republic of China. She is the author of 10 books and editor (or co-editor) of 12 handbooks; she has published about ninety articles in several different languages.

Tien-Hui Chiang is a distinguished professor at Zhengzhou University, People's Republic of China. He is a member of the World Council of Comparative Educational Societies Constitutional Standing Committee; DVP of the CSHETP, Pedagogical Department, University of Crete; a Fulbright senior scholar; distinguished scholar of the Ministry of Education, Taiwan; and Ex-President of the Taiwan Association for Sociology of Education. His specialities are sociology of education and globalization/ education policy.

\section{References}

Aldrete, G.S. (2011) The Great Courses: History of the ancient world: A global perspective. Course guidebook. Online. www.fortbendisd.com/site/handlers/filedownload.ashx?moduleinstanceid=1 78567\&dataid=105807\&FileName=3850_HistoryAncientWorld.pdf (accessed 26 April 2017).

Apostolidou, E. (2017) 'The "burden of history" and controversial issues'. Public History Weekly, 5 (12), 1-5. Online. www.researchgate.net/publication/315706503_'To_'Baros'_tes_Istorias_kai_ ta_Synkrousiaka_Zetemata_sten_Ekpaideuse'_PUBLIC_HISTORY_WEEKLY_in_Greek_English_ German (accessed 1 August 2018).

Appadurai, A. (1990) 'Disjuncture and difference in the global cultural economy'. Public Culture, $2(2), 1-24$.

Barnes, J. (2015) 'Defining world history vs global history'. H-World discussion, 31 March. Online. https://networks.h-net.org/node/20292/discussions/66052/defining-world-history-vs-globalhistory (accessed 26 April 2017).

Bentley, J.H. (1993) Old World Encounters: Cross-cultural contacts and exchanges in pre-modern times. New York: Oxford University Press.

Bentley, J.H. (1996) 'Cross-cultural interaction and periodization in world history'. American Historical Review, 101 (3), 749-70.

Brooks, G.E. (1991) 'An undergraduate world history curriculum for the twenty-first century'. Journal of World History, 2 (1), 65-79.

Brown, P.R.L. (1987) 'The world of late antiquity, AD 150-750'. In Veyne, P. (ed.) A History of Private Life: Vol. 1: From Pagan Rome to Byzantium. Cambridge, MA: Harvard University Press, 239-311.

Buell, F. (1993) 'World studies for a multicultural era'. Social Studies, 84 (2), 58-62.

Bunge, R. (1994) 'Sociological confession'. In Brown, H. (ed.) Sociology of World History Standards: Standards in world history: A sociological perspective. World-L-Forum on non-Eurocentric world history, Multiple recipients of list WORLD-L.

Burke, P. (ed.) (1991) New Perspectives on Historical Writing. Cambridge: Polity Press.

Burns, R.M. (ed.) (2006) Historiography: Critical concepts in historical studies: Vol. 5: Politics. London: Routledge.

Chow, R. (1993) Writing Diaspora: Tactics of intervention in contemporary cultural studies. Bloomington: Indiana University Press.

Christian, D. (2004) Maps of Time: An introduction to big history. Berkeley: University of California Press.

Clifford, J. (1988) The Predicament of Culture: Twentieth-century ethnography, literature, and art. Cambridge, MA: Harvard University Press.

Clifford, J. (2013) Returns: Becoming indigenous in the twenty-first century. Cambridge MA: Harvard University Press.

Collingwood, R.G. (1946) The Idea of History. Oxford: Clarendon Press.

Conway, T.R. (2007) 'Jerome Bruner'. In Kincheloe, J.L. and Horn Jr., R.A. (eds) The Praeger Handbook of Education and Psychology. Westport, CT: Praeger Publishers, 57-62. Online. https://epdf.tips/the-praeger-handbook-of-education-and-psychology-four-volumes.html (accessed 1 August 2018)

Coulby, D. (1995) 'Ethnocentricity, post modernity and European curricular systems'. European Journal of Teacher Education, 18 (2-3), 143-53. 
Craig, A., Graham, W.A., Kagan, D., Ozment, S. and Turner, F.M. (1997) The Heritage of World Civilizations. Upper Saddle River, NJ: Prentice Hall.

Curtin, P.D. (1991) 'Graduate teaching in world history'. Journal of World History, 2 (1), 81-9.

DfE (Department for Education) (2013) 'Statutory guidance: National curriculum in England: History programmes of study'. Online. www.gov.uk/government/publications/national-curriculum-inengland-history-programmes-of-study/national-curriculum-in-england-history-programmes-ofstudy (accessed 12 July 2018).

Engle, S.H. (1971) 'Global history'. In Deighton, L.C. (ed.) The Encyclopedia of Education (Vol. 4). New York: Macmillan, 438-42.

Farnen, R.F. (ed.) (1994) Nationalism, Ethnicity, and Identity: Cross national and comparative perspectives. New Brunswick, NJ: Transaction Publishers.

Featherstone, M. (ed.) (1990) Global Culture: Nationalism, globalization and modernity. London: SAGE Publications.

Friedman, J. (2007) 'Globalization'. In Nugent, D. and Vincent, J. (eds) A Companion to the Anthropology of Politics. Oxford: Blackwell, 179-97. Online. https://is.muni.cz/el/1423/ jaro2017/SAN106/um/A_Companion_to_the_ANTHROPOLOGY_of_POLITICS.pdf (accessed 2 August 2018).

Geyer, M. and Bright, C. (1995) 'World history in a global age'. American Historical Review, 100 (4), 1034-60.

Gills, B.K. and Thompson, W.R. (eds) (2006) Globalization and Global History. London: Routledge.

Giroux, H.A. (1990) 'The politics of postmodernism: Rethinking the boundaries of race and ethnicity'. Journal of Urban and Cultural Studies, 1 (1), 5-38.

Goddard, V.A., Llobera, J.R. and Shore, C. (eds) (1994) The Anthropology of Europe: Identities and boundaries in conflict. Oxford: Berg.

Greaves, R.L. et al. (1990) Civilizations of the World: The human adventure. New York: Harper and Row.

Gregoriou, Z. (2001) 'The in-betweeness of postcolonial pedagogy: Teachers as receptacles and transistors of difference in Derrida's Khora'. In Biesta, G.J.J. and Egéa-Kuehne, D. (eds) Derrida and Education. London: Routledge, 1-27.

Hausen, E. (1996) Human History at the Crossroads: Where do we go from here? Westport, CT: Bergin and Garvey.

Hourdakis, A. (1996) 'A global dimension via the teaching of the "ancient world": Theoretical concepts and an empirical approach from Greek primary textbooks'. Mediterranean Journal of Educational Studies, 1 (2), 157-82.

Ivrideli, M., Papadakis, N. and Fragkoulis, I. (2003) 'European integration, multiculturalism and the intended curriculum of primary education in Greece: Myths and realities'. In Ross, A. (ed.) A Europe of Many Cultures. London: $\mathrm{CiCe}, 411-18$.

Jenkins, K. (ed.) (1997) The Postmodern History Reader. London: Routledge.

Judt, T. and Snyder, T. (2012) Thinking the Twentieth Century. New York: Penguin Press.

Kahne, J. and Westheimer, J. (2003) 'Teaching democracy: What schools need to do'. Phi Delta Kappan, 85 (1), 34-66.

Kishlansky, M. et al. (1995) Societies and Cultures in World History. New York: HarperCollins.

Leont'ev, D.A. (1994) 'The concept of personal sense through the ages'. Multidisciplinary Newsletter for Activity Theory, 15/16, 9-13.

Mader J.N. (2012) 'Creating critical thinking in world history surveys: Innovations with primary sources, film, and the internet'. Middle Ground Journal, 4, 1-15. Online. http://resources.css. edu/academics/his/middleground/articles/mader.pdf (accessed 26 April 2017).

Manitoba Education and Training (1993) Social Studies Grade 8 Curriculum Guide: Revised. Winnipeg: Manitoba Education and Training.

Mazlish, B. (1998) 'Comparing global history to world history'. Journal of Interdisciplinary History, 28 (3), 385-95.

Mazlish, B. (2006) The New Global History. New York: Routledge.

Mazlish, B. and Buultjens, R. (eds) (1993) Conceptualizing Global History. Boulder, CO: Westview Press.

Mazlish, B. and Iriye, A. (2005) The Global History Reader. New York: Routledge.

McCarthy, T.P. (ed.) (2012) 'Interlude: Who controls the past controls the future: Interview with David Barsamian, Boulder, Colorado, 1992'. In Zinn, H. The Indispensable Zinn: The essential writings of the "people's historian". Ed. McCarthy, T.P. New York: New Press, 66-81.

McKellar, I. (1999) 'Using sources in history teaching'. In Bennett S. (ed.) Interpreting the Past Using Sources in History Teaching: EUROCLIO, Bulletin 11. 
McNeill, W.H. (1986) Polyethnicity and National Unity in World History. Toronto: University of Toronto Press.

McNeill, W.H. (1992) The Global Condition: Conquerors, catastrophes, and community. Princeton: Princeton University Press.

Moniot, H. (1993) Didactique de l'histoire. Paris: Nathan.

NCHS (National Center for History in the Schools) (1995) 'Basic principles'. Online. https://phi. history.ucla.edu/nchs/standards-grades-k-4/developing-standards-grades-k-4/ (accessed 27 April 2017).

NCHS (National Center for History in the Schools) (1996) 'Developing standards' Online. https://phi.history.ucla.edu/nchs/preface/developing-standards/ (accessed 1 August 2018).

Newman, F. and Holzman, L. (1993) Lev Vygotsky: Revolutionary scientist. London: Routledge.

Nielsen, B. (2013) 'L'Unesco et le culturellement correct'. Gradhiva, 18, 74-97. Online. http://gradhiva.revues.org/2713 (accessed 12 July 2018).

Nietzsche, F. (1976) The Use and Abuse of History. Trans. Collins, A. Indianapolis, IN: Bobbs-Merrill.

Oakes, J. and Lipton, M. (1999) Teaching to Change the World. Boston: McGraw-Hill.

Peyrot, J. (1986) 'Editorial: Grandeur et misère'. Historiens et geographes, 312, 334-8.

Peyrot, J. (1990) 'Editorial: Programmes du secondaire: la nouvelle donne'. Historiens et geographes, 327, 19-23.

Peyrot, J. (1999) L'enseignement de l'histoire en Europe. Paris: Hachette.

Pomeranz, K. (2002) 'Beyond the East-West binary: Resituating development paths in the eighteenth-century world'. Journal of Asian Studies, 61 (2), 539-90.

Reddy, W.M. (2001) The Navigation of Feeling: A framework for the history of emotions. Cambridge: Cambridge University Press.

Robbins, K. (1993) History, Religion and Identity in Modern Britain. London: Hambledon Press.

Rosenwein, B.H. (2010) 'Problems and methods in the history of emotions'. Passions in Context, 1 (1), 1-32. Online. www.passionsincontext.de/uploads/media/01_Rosenwein.pdf (accessed 16 August 2017).

Schäfer, W. (1993) 'Global history: Historiographical feasibility and environmental reality'. In Mazlish, B. and Buultjens, R. (eds) Conceptualizing Global History. Boulder, CO: Westview Press, 47-69.

Scheer, M. (2012) 'Are emotions a kind of practice (and is that what makes them have a history)? A Bourdieuian approach to understanding emotion'. History and Theory, 51 (2), 193-220.

Seminole County Board of Public Instruction (1986) United States History Curriculum. Eighth Grade Social Studies Curriculum. Online. https://files.eric.ed.gov/fulltext/ED335292.pdf (accessed 1 August 2018).

Singer, A.J. (2011) Teaching Global History: A social studies approach. New York: Routledge.

Slater, J. (1995) Teaching History in the New Europe. London: Cassell.

Sotshangane, N. (2002) 'What impact globalization has on cultural diversity?'. Alternatives: Turkish Journal of International Relations, 1 (4), 214-31.

Stearns, P.N., Adas, M. and Schwartz, S.B. (2007) World Civilizations: The global experience. 6th ed. Boston: Longman.

Stradling, R. (2003) Multiperspectivity in History Teaching: A guide for teachers. Strasbourg: Council of Europe.

Tait, P. (2015) 'The trouble with choosing what history to teach'. The Telegraph, 7 October. Online. www.telegraph.co.uk/education/educationopinion/11915034/The-trouble-with-choosing-whathistory-to-teach.html (accessed 16 August 2017).

Turk, D.B., Dull, L.J., Cohen, R. and Stoll, M.R. (2014) Teaching Recent Global History: Dialogues among historians, social studies teachers, and students. New York: Routledge.

Vieux, S. (1994) 'In the shadow of neo-liberal racism'. Race and Class, 36 (1), $23-32$.

Weaver, V.P. (1988) 'Education that is multicultural and global: An imperative for economic and political survival'. Social Studies, 79 (3), 107-9.

Weil, P. (1990) L'Art de Vivre en Paix. Paris: United Nations Educational, Scientific and Cultural Organization.

Wertsch, J.V., del Río, P. and Alvarez, A. (eds) (1995) Sociocultural Studies of Mind. Cambridge: Cambridge University Press.

Wolf, E.R. (1982) Europe and the People without History. Berkeley: University of California Press.

Yurco, F.J. (1994) 'How to teach ancient history: A multicultural model'. American Educator, $18(1), 32-7$. 